\title{
The Influence and the Education Path of the WeChat Friend Circle on Post-90 College Students' Ideological and Political Work
}

\section{Cheng Fen}

Hubei Business College, Wuhan, Hubei Province, 430079

Keywords: WeChat friend circle; post-90 college students; ideological and political work

\begin{abstract}
The Wechat friend circle is a special communication media among post-90 college students. All activities and all discourses of the WeChat friend circle influence the post-90 college students and bring many influences and challenges to the ideological and political work of college students, including both positive and negative effects. Facing the self-media environment of the WeChat friend circle, it is necessary for college ideological and political work to make use of the platform of the WeChat friend circle and follow the e-learning and life characteristics of the post-90 college students group in an effort to explore the educational path and construction of the post-90 college students' ideological and political education. The long-term mechanism of undergraduates' ideological and political education promotes the scientific, normal, and standardized development of post-90 college students' ideological and political education under the environment of the WeChat friend circle.
\end{abstract}

\section{Introduction}

As a new phenomenon in social networks, the characteristics of self-media are consistent with the pursuit of novelty and fashion personality among the post-90s young college students. Various self-media applications have already penetrated into every aspect of college students' lives. Specifically, the main media platforms include forums (posting bars), blogs (QQ space), Weibo, and WeChat. Among them, WeChat came from behind. As of the second quarter of 2014, WeChat active users have reached 438 million, nearly three times the number of active users of Weibo, and have become the fastest growing self-media tools. Survey data from 15 universities in Beijing and Shanghai shows that the proportion of students using WeChat is close to $90 \%$. WeChat friend circle has become an important channel for students to post or receive news, which shows that the popularity of the WeChat and WeChat friend circle is high. Under such circumstances, the WeChat friend circle has a lot of influence on the life, learning, concept world, and friends of college students in the post-90 periods, which has brought a great deal of challenges to the post-90s college students' ideological and political education. [1] Therefore, it is of great practical significance and long-term significance to study the issue of the ideological and political education of college students in the post-90s under the WeChat friendship environment.

\section{The Definition, Function and Characteristics of the WeChat Friend Circle}

The WeChat circle of friends is an extension of the WeChat platform's functions. It is mainly used for social activities and interactions among friends. Through WeChat friends, you can send pictures, text, music, videos, etc. to achieve a shared and interactive effect. Social network theory to interpret [2], WeChat's circle of friends has a solid and rich theoretical basis, not only conforms to the principles of linking and embedding theory, but also conforms to the principles of social capital and structural hole theory.

\subsection{Definition of WeChat friend circle}

The WeChat friend circle is an important part of the WeChat media platform. It is a kind of network of friends and networks that exist in the online society. It can be called a virtual network micro-community. In this community, its structure consists mainly of the relationship between 
friends, so it is intimate and interactive. In terms of the value of the WeChat friend circle, the biggest problem is to facilitate the free exchange of people, provide people with a free exchange platform and media circles, enhance the user's social capital stock, greatly enhance the user's social resources.

\subsection{Function of WeChat friend circle}

WeChat is an extension of QQ. It is also a development version and an enhanced version. It has many functions and advantages [3]. As an important feature of the WeChat platform, the WeChat friend circle also has several powerful features. Fistly, with strong social capabilities, it can increase the user's social capital stock. As a micro-platform for friends making friends on the Internet, the basic function of the WeChat friend circle is a communication function. Through this circle of friends, users can exchange ideas with their friends and exchange their own recent living conditions and working conditions and learning conditions. You can also exchange some of your own more intimate things. Through the likes and comments, the friends in WeChat friend circle can interact with each other to enhance mutual trust. At the same time, friends can also communicate with other friends in WeChat friend circle. The WeChat friend circle has powerful social value and function, which can greatly enhance the trust between friends and provide a more secure and free communication network, thus greatly enhancing WeChat users' social capital stock. Secondly, with educational functions, it can enhance the cultural quality of users. In addition to its powerful social functions, the WeChat friend circle also has educational and learning functions. In the friend circle of WeChat, users talk about each other's views on each event and certain phenomenon. Through this exchange, they can enhance mutual understanding and promote the user's knowledge in one aspect, such as talking about health, talking about work, talking about life attitude, talking about life and so on, which will enhance the ability of the users of WeChat friends to learn and educate, and highlight the hidden education and learning functions of the circle of friends.

\subsection{The characteristics of WeChat friend circle}

Virtuality is in common with reality, and virtuality is greater than reality. The WeChat friend circle is an important part of the WeChat platform. It has the characteristics of general network activities. The main body of communication is in a state of communication and dialogue under the condition of no real meeting. It is in an imaginary state of space between each other. The content and image are not necessarily completely true. The subject of WeChat contacts is a familiar person. After all, the displayed things should have a lot of reality. They can reflect the life, learning, hobbies, psychological thoughts, personality characteristics of the communication subject so they should be better than a single person. Internet chat can reflect a certain degree of real life.

Privacy and security exist at the same time. The WeChat friend circle is an exchange platform for exchanges and friends. It presents a space for private activities. It shows personal life, learning, hobbies, and tourism. It does not usually involve public domain hotspots. The focus is on issues, so it is very private and life-like. This is the direction of development of all platforms under the microenvironment. Security is mainly reflected in the WeChat friend circle can directly exclude friends who do not know, so as to ensure the safety of the WeChat circle of friends and improve its security.

Fast, as a communication platform, the WeChat friend circle can provide timely and various content and information for the exchange subjects and provide all kinds of necessary resources. The WeChat friend circle exists due to the fact that the user is maintained by a friend relationship. Within this circle, it is very likely that it is a repetitive overlap.

\section{The Influence of WeChat Friend Circle on Ideological and Political Work of Post-90 College Students}

The WeChat friend circle highlights the characteristics of the post-90s college students' online life. In addition to some positive influences, the WeChat friend circle has brought more challenges to post-90 college students' political education. 


\subsection{On the contents of ideological and political work of post-90 college students}

As a communication platform and circle, the WeChat friend circle serves as a place for free speech. The contents of it are very broad.These information contents have impacted on the original positive energy content system of post-90 university students' ideological and political education.

\subsection{On the mode and method of ideological and political work of post 90s college students.}

As a special feature of WeChat from the media, the WeChat friend circle has a significant impact on the way of life, study, psychology, and ideology and culture of post 90s college students. It has become a very keen social way for college students in the 90s. This is actually a post-90s phenomenon. The mode and method of the ideological and political education work of college students pose a challenge, which is to reform the existing traditional education model, integrate the use of WeChat, Weibo, QQ and other online education platforms, and build a network of ideological and political education mode and method system.

\subsection{On the effective achievements of ideological and political work of post-90 college students}

The WeChat friend circle and other micro-environmental networks have triggered a lot of interest among college students and have had an important impact on their lives, learning, friends, and psychology, and have also demonstrated the different behaviors and different attitudes of different post-90 college students. The way of interaction and life style is a manifestation of the networked way of survival of post-90 college students. Specifically, the WeChat friend circle has had a number of adverse effects on the post-90 college students themselves. This has led to the dissimilation and variation of the college students' values after the 90s. The influence of WeChat friend circle on college students and college teachers has greatly affected the effective advancement of post-90s college students' ideological and political work.

Above all, we can see that the WeChat friend circle, as an important part and function of the WeChat network platform and media, has brought a lot of influence on the college students themselves and their ideological and political education work in the 90s, and has also brought a lot of challenges. From one aspect, it shows that the post-90s college students' ideological and political education is outdated and not advancing with the times. The integration of traditional education mode and online platform education mode is not enough. Modern ideological and political education in modern colleges and universities has constructed all kinds of self-media ideological and political education positions.

\section{The Development and Use of WeChat Friend Circle is an Education Path to Innovate Ideological and Political Work Post-90 college students}

On the basis of this situation, we must grasp the law of Wechat on the Internet, according to the characteristics of undergraduate students after 90 years, according to the laws of ideological and political education, innovation and development from all aspects, to build a long-term mechanism for the ideological and political work of post-90 college students, to enhance the effectiveness and pertinence of post-90 college students' ideological and political work.

At the national level, we should guide the healthy development of WeChat from the aspects of the rule of law, policies, and social environment, and construct a good WeChat environment for the education of ideological and political work for undergraduates after 90s.

At the school level, efforts should be made to innovate the post-90s college students' ideological and political education model, and actively carry out post-90 postgraduate ideological and political education work to promote the post-90s college students' physical and mental health development. The WeChat circle of friends has brought many influences and challenges to the ideological and political work of post-90 college students. It has also brought about the opportunity and enlightenment of reform, innovation and development for post-90s college students' ideological and political education.

Efforts will be made to build the value orientation of compound innovation and promote the 
healthy development of post-90 university students' ideological and political education. The value orientation and development concept are related to the direction and trend of ideological and political education.Ideological and political workers in colleges and universities should, based on the characteristics of college students in the 90's and the laws of ideological and political education, and the requirements of college education, adhere to the orientation of education as a fundamental. The value orientation of the post-90s post-90s undergraduate students of WeChat will be promoted by integrating the content, model, goals, and environmental platform construction of post-90 college students' ideological and political education into the healthy track of scientific development, informational development, and systematic development.

In response to the development of the WeChat friend circle and its influence on post-90s college students, the content system of ideological and political education has been continuously enriched.The network trust, network responsibility, WeChat use ability, mental health issues, employment problems, and practical difficulties have been incorporated into the content system of post-90 college students' ideological and political education work, and many contents in the WeChat friend circle can also be used as educational materials. At the same time, we must pay attention to the micro-era transition of ideological and political discourse so as to continuously enrich the content of post-90s college students' ideological and political education and continuously enhance the pertinence of ideological and political education.

The concept and awareness of the micro-era will be firmly established, and the quality and ability of post-90 college students' ideological and political educators will be continuously improved. Ideological and political workers in colleges and universities are concrete implementers of ideological and political work of college students, and their quality directly affects the post-90s college students' ideological and political education. Universities and colleges should guide ideological and political workers in colleges and universities through various platforms and means. They should fully improve the overall quality and comprehensiveness of college ideological and political teachers from the aspects of professional knowledge, professional skills, ideology and politics, values, and Weibo WeChat knowledge and technology.

The students themselves should give full play to their subjective initiative. They should do their own self-purification and self-education work, and constantly improve their own network selfmedia literacy and ability to use. The key reason is that The WeChat friend circle is suitable for the needs and personality development of the youth groups. The influence of WeChat friend circle on post-90s college students and their ideological and political work needs to be handled well. The key is also that the self-education ability of college students after 90s should be improved.

Actively participating in school ideological and political education activities and campus cultural activities is in order to form their own correct values and friendship concept. In this regard, the ideological and political education activities of schools and other campus activities are important platforms for the growth of colleges and universities in the post-90s, especially for the development of students' ideological and moral qualities. Therefore, after 90s, college students should actively participate in The school's youth education activities will continue to enhance its online social responsibility, network norms, and trust consciousness so as to build its own correct outlook on life, world outlook, values, and friendship, so as to continue to lead its own words and deeds in the WeChat friend circle. The network technology is the basic skills that postgraduate students must possess. For this reason, undergraduates should actively learn computer and network knowledge and skills of antivirus and antivirus, learn to delete bad information, and learn how to use the Internet technology to deal with all kinds of undesirable elements on the Internet, so as to continuously improve the 90 college students themselves in WeChat friends. The self-defense ability of self-defense in the circle.

\section{Conclusion}

In short, the WeChat circle of friends, as a platform for dating activities under the WeChat environment, has brought many challenges to the ideological and political work of post-90 college students, and has also brought a whole new work situation. At present, the key point is that 
ideological and political educators in universities must renew their ideas. We should analyze the pros and cons of WeChat circle friend and keep up with the times. We must pay full attention to the challenges and opportunities brought by the WeChat circle of friendship to ideological and political education in universities and make good use of them. The political education mechanism [12] continuously promotes the self-education ability of contemporary college students and puts the ideological and political education work into practice, effectively enhancing the effectiveness and timeliness of post-90s college students' ideological and political work.

\section{References}

[1] Yu Jie, Shi Jing, Wei Hongsu, Path Choices for Ideological and Political Education of Post-90s College Students under the Micro-era Perspective, Science and Technology News, 2015(3), 172

[2] Liu Guanhua, Interpretation of the Wechat Friend Circle from the Perspective of Social Network Theory, Journal of News and History, 2013, Issue 4, 47-48

[3] Zhao Yuanwei, Analyzing the Communication Advantages of the WeChat Friend CircleTaking the Circle of Friends in the QQ Space as an Example, "China Newcom" No. 12 of 2014 4243

[4] Yu Yang, The Psychological Motive behind "Zambia" - Taking the WeChat Friend Circle as an Example, Psychological Technology and Applications 2014 No. 11 60-61 